\title{
潮流発電装置据付時の水中動摇特性と 施工限界の推定
}

\author{
松田 信彦 1 - 倉原 義之介 1 ・江口 三希子 1 ・ \\ 津田 宗男 1 ・栗原 明夫 2 ・河邊 寛 3 \\ 1正会員＼cjkstart東亜建設工業（株）技術研究開発センター（テ230-0035 横浜市鶴見区安善町1-3） \\ E-mail:n_matsuda @ toa-const.co.jp \\ 2正会員＼cjkstart東亜建設工業（株）土木事業本部設計部 \\ （₹163-1031 東京都新宿区西新宿3-731 新宿パークタワー31F） \\ 3非会員 元ベルナンブコ大学教授
}

\begin{abstract}
東日本大震災以降，我が国のエネルギー政策の見直しが行われ，海洋再生エネルギーの利用拡大が求めら れている，潮流発電は天候に左右されず, 昼夜問わず発電量が安定していることや, 潮の干満により年間 を通して発電量を予測できる特徴がある。潮流発電装置の据付作業では波浪や潮流の作用により, 船体や 水中の吊荷が動摇して据付精度が低下寸るため, 船体や吊荷の動摇特性を把握して施工寸ることが重要で ある. 本研究は, 潮流発電装置据付時の動摇について模型実験で特性を明らかにした。 また, 動摇解析を 用いて動摇特性を再現し, 海象条件からではなく吊荷の動摇から作業可否判定をする方法を提案した.
\end{abstract}

Key Words : tidal current power generation system, floating crane,ship motions, limit condition of marine construction works

\section{1. はじめに}

東日本大震災の影響による電力不足や温室効果ガスの 排出量削減を背景に，海洋再生可能エネルギーの利用拡 大が進められている1)。潮流発電は発電装置を海底に設 置するため台風などの天候に左右されず，昼夜問わず発 電量が安定していることや, 潮汐流により年間を通して 発電量を予測できる特徵がある.

潮流発電装置の据付工事では，波浪や潮流の作用によ り作業船や吊荷が動摇して安全性や据付精度が低下寸る。 図-1 は作業中止基準と施工限界の海象との関係を示し たイメージ図である。ここでは，全ての作業が安全にで きる基準を作業中止基準とし，施工に必要な玉掛けや投 錨などの作業ができ，施工管理基準内の精度で施工がで きる限界を施工限界とした。一般的に作業中止基準や施

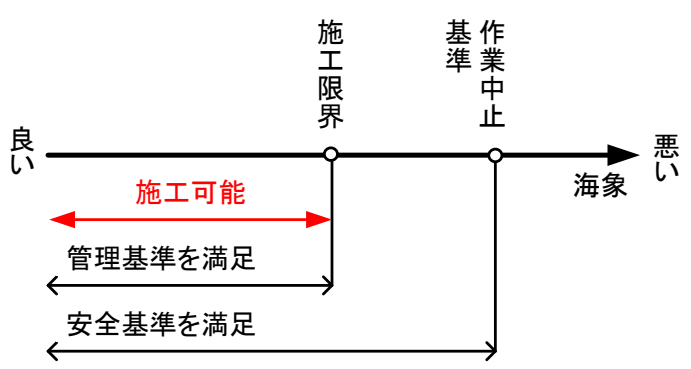

図-1＼cjkstart作業中止基準と施工限界
工限界は，気象や海象，作業内容などの複合的な影響を 考慮して，会社や船団ごとに経験的に基準が決められて いる. しかし，基準值にばらつきが大きく実際の工事で 施工精度を考慮した作業可否を判断することは容易では な(2)3)，そのため，海象条件からではなく作業船や吊荷 の動摇と言う観点から作業可否判定を試みた。

本研究は複雑な形状をした潮流発電装置を，起重機船 で水中に吊下げた時の動摇特性を模型実験で明らかにし た。 また，河邉ら ${ }^{45)}$ )が開発した動摇解析モデルを複雑な 形状の吊荷に対して拡張し，水中の動摇を再現し施工限 界条件について検討した.

\section{2. 起重機船模型による動摇実験}

\section{(1) 実験概要}

実験に使用した潮流発電装置は，長崎県五島市での潮 流発電実証事業で計画されたもので，図-2 のようにナ セルとそれを支えるタービンベースからなっており上下 を分離することができる構造となっている，装置全体を 一括設置する場合は大型の $2200 t$ 吊起重機船を使用する 計画である，本論ではこの状態の発電装置を全体を「一 括」と称す．また，メンテナンスでナセルや回転翼など の上部のみを脱着する時は小型の700t 吊起重機船やDP 


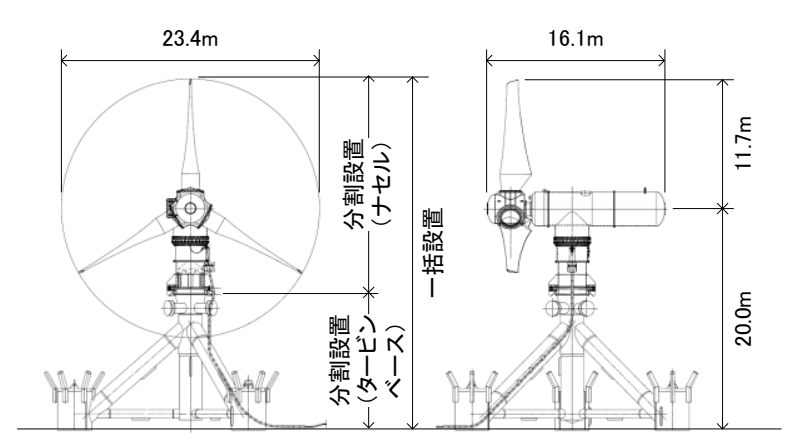

図-2 潮流発電装置

表-1 起重機船の緒元

\begin{tabular}{|l|r|r|r|r|}
\hline \multirow{2}{*}{} & \multicolumn{2}{|c|}{ 起重機船A 2200t吊 } & \multicolumn{2}{|c|}{ 起重機船B 700t吊 } \\
\cline { 2 - 6 } & 現地 & 実験(1/50) & 現地 & 実験(1/50) \\
\hline 船長 & $90.0 \mathrm{~m}$ & $1.800 \mathrm{~m}$ & $56.3 \mathrm{~m}$ & $1.125 \mathrm{~m}$ \\
\hline 幅 & $41.0 \mathrm{~m}$ & $0.820 \mathrm{~m}$ & $25.6 \mathrm{~m}$ & $0.513 \mathrm{~m}$ \\
\hline 高さ & $7.0 \mathrm{~m}$ & $0.140 \mathrm{~m}$ & $4.4 \mathrm{~m}$ & $0.088 \mathrm{~m}$ \\
\hline 哭水 & $4.2 \mathrm{~m}$ & $0.084 \mathrm{~m}$ & $2.6 \mathrm{~m}$ & $0.053 \mathrm{~m}$ \\
\hline 重量 & $15,533 \mathrm{t}$ & $124.3 \mathrm{~kg}$ & $3.792 \mathrm{t}$ & $30.3 \mathrm{~kg}$ \\
\hline ジブトップ高さ & $98.6 \mathrm{~m}$ & $1.971 \mathrm{~m}$ & $61.6 \mathrm{~m}$ & $1.232 \mathrm{~m}$ \\
\hline アウトリーチ & $51.9 \mathrm{~m}$ & $1.038 \mathrm{~m}$ & $32.4 \mathrm{~m}$ & $0.649 \mathrm{~m}$ \\
\hline 固有周期 Roll & $9.7 \mathrm{~s}$ & $1.37 \mathrm{~s}$ & $7.4 \mathrm{~s}$ & $1.05 \mathrm{~s}$ \\
\hline 固有周期 Pitch & $9.0 \mathrm{~s}$ & $1.27 \mathrm{~s}$ & $7.3 \mathrm{~s}$ & $1.03 \mathrm{~s}$ \\
\hline
\end{tabular}

表-2 潮流発電装置の気中重量と水中重量

\begin{tabular}{|l|c|r|r|r|}
\hline \multirow{2}{*}{} & \multicolumn{2}{|c|}{ 一括設置 } & \multicolumn{2}{c|}{ 分割設置 } \\
\cline { 2 - 5 } & 現地 & 実験 $(1 / 50)$ & 現地 & 実験 $(1 / 50)$ \\
\hline 気中重量 & $788.7 \mathrm{t}$ & $6.3 \mathrm{~kg}$ & $176.1 \mathrm{t}$ & $1.4 \mathrm{~kg}$ \\
\hline 水中重量 & $589.1 \mathrm{t}$ & $4.7 \mathrm{~kg}$ & $61.3 \mathrm{t}$ & $0.5 \mathrm{~kg}$ \\
\hline
\end{tabular}

船を用いて効率的に作業を行うことを想定している.こ の状態の発電装置を「分割」と称寸.また， $2200 t$ 吊起 重機船を起重機船A，700t 吊起重機船を起重機船B す. 実験は潮流の速い現場海域の特徵を考慮して, 波浪 と流速の条件を変えて起重機船の動摇と水中吊荷の動摇 につて調べた.

\section{（2）実験水槽, 起重機船と潮流発電装置の緒元}

実験は縮尺1/50 の起重機船模型と潮流発電装置模型を 製作して，一括設置（全体）と分割設置（ナセル）の実 験を行った。表-1 と表-2 はそれぞれ起重機船と潮流発 電装置の緒元である. 図-3 は起重機船A の実験の様子 である. 模型を水槽に浮かべて係留し，発電装置を水面 から回転翼の中心まで深度 $20 \mathrm{~m}$ （模型 $0.4 \mathrm{~m}$ ）まで降ろ した状態で，波と流れを作用させて船体と吊荷の動摇を 測定した. 起重機船B についても同様に吊荷をナセルに 代えて行った.

\section{(3) 計測項目と計測方法}

起重機船の動摇は, 3 軸ジャイロスコープと加速度セ

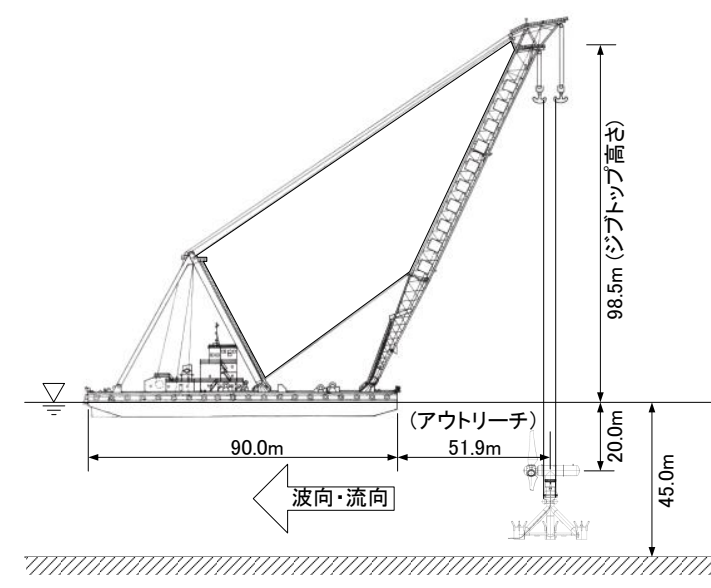

図-3 起重機船Aの実験条件

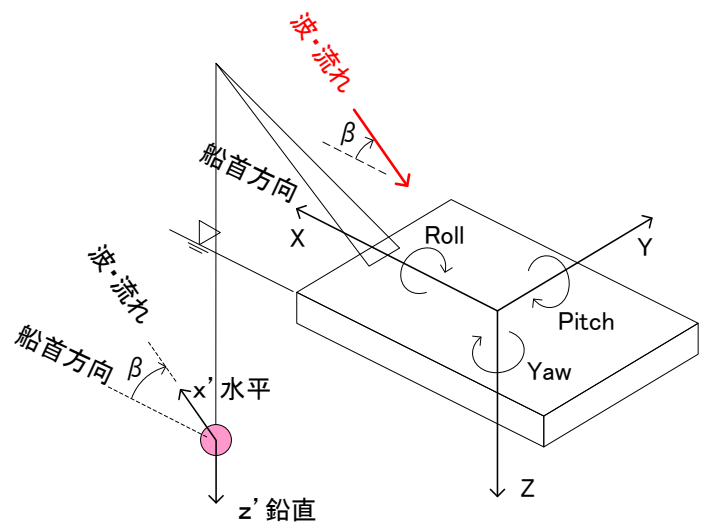

図-4 起重機船と吊荷の動摇成分

ンサーを内蔵した小型姿勢角検出器を使用した。 また, 水中吊荷の動摇は水槽側面から撮影したビデオ映像から， 運動解析ソフトウェアを用いて測定した. 図-4 は起重 機船と吊荷の動摇成分である. 波・流れの向きは水槽縦 断方向であり, 起重機船模型を回転させて入射角 $\beta$ を変 えている. ビデオ撮影は水槽側面のガラスから水槽横断 方向に撮影しているため, 水中吊荷の水平方向は船体と 同じではなく，波・流れと同じ方向になっている．波高 は容量式波高計，流速は電磁流速を船体中心から沖側一 6.6m離れた場所に設置して計測した.

\section{(4) 実験条件と実験ケース}

実験ケースは表-3 に示寸通りである．表中の起重機 船A 4 , 4 本のワイヤーで発電装置全体を吊る4 点吊り である.また，起重機船Bは， 2 本のワイヤーでナセル を吊る2点吊りで実験を行った.

\section{3. 実験結果}

\section{(1) 起重機船の固有周期}

動摇実験に先立って, 吊荷の無い状態で起重機船模型 の Roll と Pitch の自由振動実験を実施して固有周期を求 めた. 起重機船Aの固有周期はRoll 9.7s, Pitch 9.0s, 起重 
表-3 実験ケース

\begin{tabular}{|c|c|c|c|c|c|c|c|}
\hline \multirow{2}{*}{$\begin{array}{c}\text { CASE } \\
\text { No. }\end{array}$} & \multirow{2}{*}{ 起重 } & \multirow[b]{2}{*}{ 吊荷 } & \multicolumn{4}{|c|}{ 入射波 } & \multirow{2}{*}{$\begin{array}{l}\text { 流速 } \\
{[\mathrm{m} / \mathrm{s}]}\end{array}$} \\
\hline & & & $\begin{array}{c}\text { 入射角 } \\
\text { [deg] }\end{array}$ & $\begin{array}{l}\text { 周期 } \\
\text { [sec] }\end{array}$ & $\begin{array}{c}\text { 波高 } \\
\text { [m] }\end{array}$ & 種類 & \\
\hline 1 & A & 一括 & 0 & 10 & $0.5,1.0,1.5,2.0$ & 規則波 & 0 \\
\hline 2 & A & 一括 & 0 & $4,6,8,10,12,14$ & 1.0 & 規則波 & 0 \\
\hline 3 & A & 一括 & 0 & 10 & 1.0 & 規則波 & $0,0.5,1.0,1.5$ \\
\hline 4 & A & 一括 & $0,45,90$ & 6 & 1.0 & 規則波 & 0 \\
\hline 5 & B & 分割 & 0 & $4,6,8,10$ & 1.0 & 規則波 & 0 \\
\hline 6 & A & 一括 & 0 & $4,6,8$ & 1.0 & 不規則波 & 0 \\
\hline
\end{tabular}

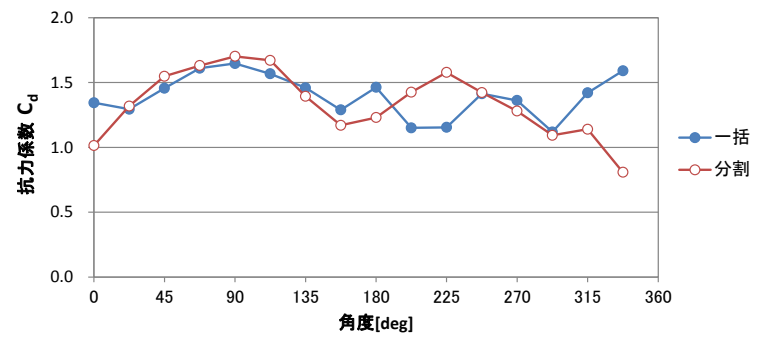

図-5 潮流発電装置の抗力係数

機船B の固有周期はそれぞれ7.4s, 7.3s であった。

\section{(2) 潮流発電装置の抗力係数}

発電装置の形状が複雑で一括設置では非対称形状であ ることから，一括と分割の抗力実験を行った．実験は水 中に固定した発電装置に一定流速 $1.0 \mathrm{~m} / \mathrm{s}(0.14 \mathrm{~m} / \mathrm{s}$ 模型 $)$ を当て, 装置に作用する流体力を3分力計で測定した. また，据付時の回転翼のPitch 角度は，流れの影響を最 小限とするため，据付時と同じフェザリングに設定して いる。一括と分割の実験結果を図-5 に示寸。潮流発電 装置の抗力係数は $0.8 \sim 1.7$ 程度である.

\section{(3) 起重機船の動摇特性}

図-4に定義した起重機船と吊荷の各動摇成分につい て整理した. 起重機船の動摇角度と水中吊荷（一括，分 割）の動摇量は，全て片振幅を示している.

\section{a) 波高の影響 (CASE 1)}

図-6 は表-3 の実験CASE 1 における入射波波高と船体 動摇角および吊荷動摇量の関係を示したものである.

図-7 は実験CASE 1 における波高と吊荷動摇速度の関係 を示したものである.

・波高に比例して船体動摇角と吊荷動摇量は増加する。

- 船体Pitch と吊荷鉛直の傾向は，ほぼ一致しており 連動している．これは波が船首方向から入射する と, 起重機船のPitch が卓越し, クレーンのジブト ップが上下に動摇するため， ジブトップから吊り 下げられた吊荷は鉛直方向に動摇するためである。 ・このケースでは波が船首から入射するため，船体 Roll と吊荷水平は小さく, 波高が増加してもあまり 変化しない. 吊荷水平は吊荷が水中にあるため水 の抵抗を受けて動摇量が小さくなっている.

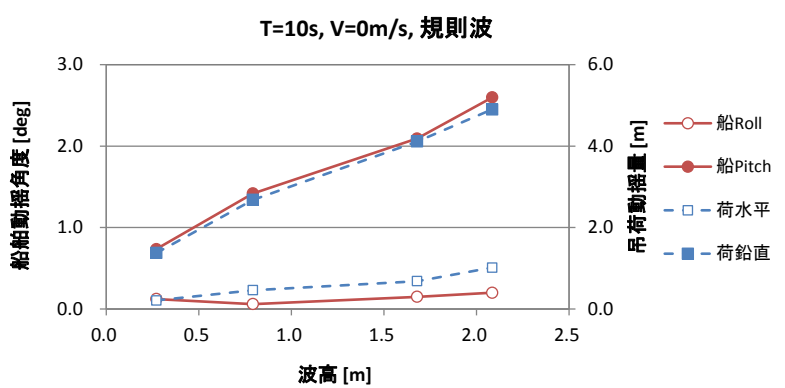

図-6 波高と動摇の関係

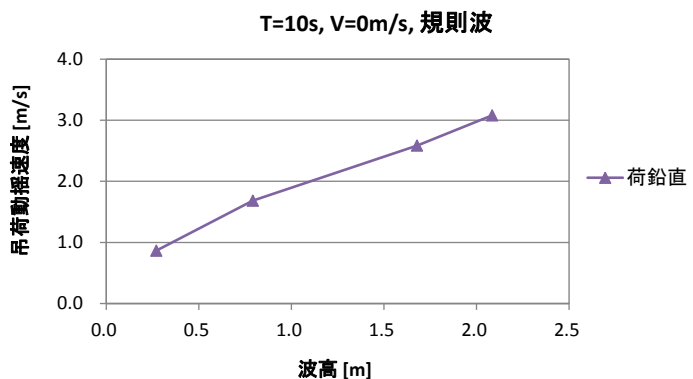

図-7 波高と吊荷の動摇速度の関係

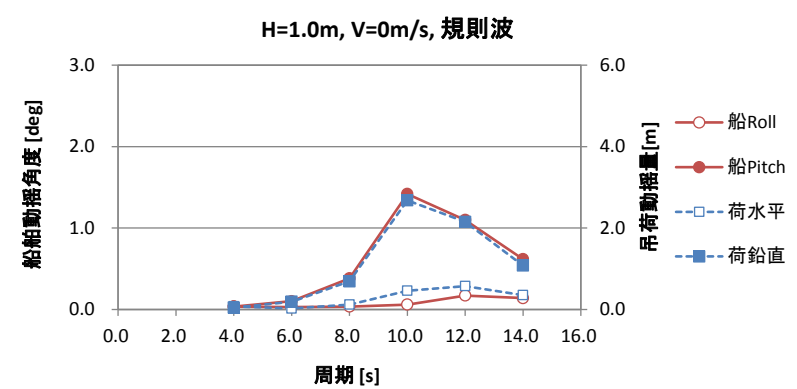

図-8＼cjkstart周期と動摇の関係

・吊荷動摇速度は波高に比例して増加する.

\section{b) 周期の影響 (CASE2)}

図-8 は表-3 の実験CASE 2 における入射波周期と船体 動摇角および吊荷動摇量の関係を示したものである.

- 船体Pitch と吊荷鉛直の傾向は，ほぼ一致しており 連動している.

・船体Pitch と吊荷鉛直の動摇は，周期10sで動摇が最 大になる．これは，起重機船AのPitch の固有周期は $9.0 \mathrm{~s}$ に同調したためで，吊荷鉛直は船体Pitch の影響 を強く受けているためである。

・船体Roll はPitch よりも固有周期が長く，周期が $10.0 \mathrm{~s}$ より長くなると動摇が増加する.

・吊荷水平は，周期が $8.0 \mathrm{~s}$ より長くなると動摇が増加 する.

\section{c) 流れの影響 (CASE3)}

図-9 は表-3 の実験CASE 3 における流速と船体動摇角 および吊荷動摇量の関係を示したものである.

・船体Pitch と吊荷鉛直の傾向は，ほぼ一致しており 連動している. 


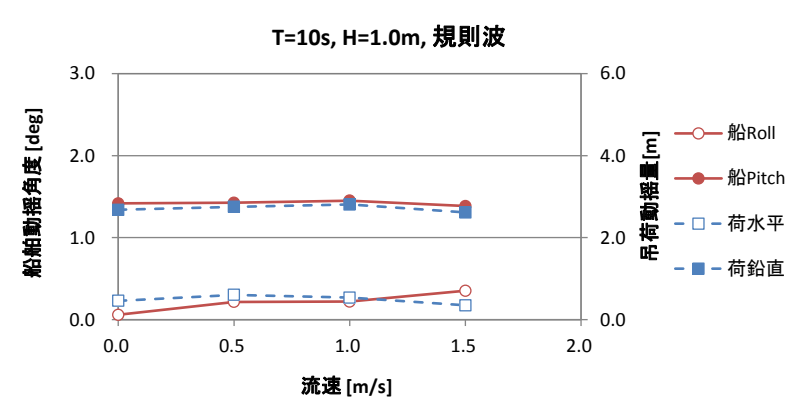

図-9 流速と動摇の関係

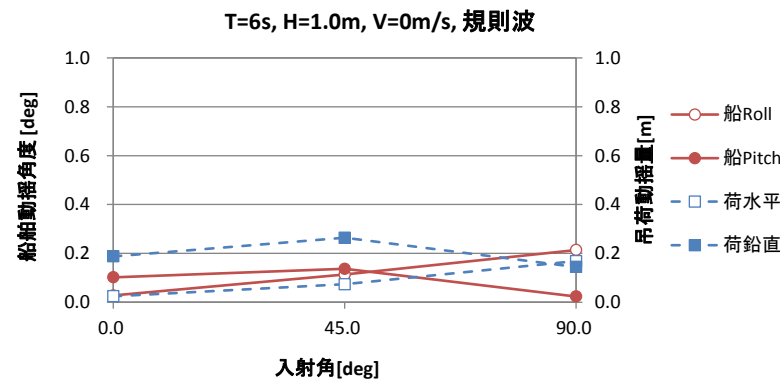

図-10 入射角之動摇の関係

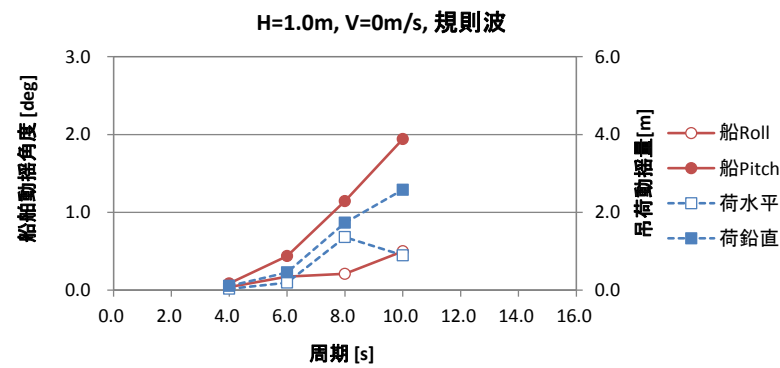

図-11 起重機船 B の周期と動摇の関係

・船体Pitch と吊荷鉛直の動摇は，流速が増加しても ほぼ一定であり流速の影響は小さい.

・船体Roll は流速が増加すると，わずかに船体動摇が 増加する.

\section{d) 入射角の影響 (CASE4)}

図-10 は表-3 の実験CASE4 における波の入射角と船体 動摇角および吊荷動摇量の関係を示したものである.

- 入射角が $0^{\circ}$ から $90^{\circ}$ 一変化すると, 船体動摇角は Rollが増加し，Picthは45 を超えると減少する.

・船体Pitch と吊荷鉛直の傾向は，ほぼ一致しており 連動している.

・船体Roll と吊荷水平の傾向は，ほぼ一致しており連 動している.

- 入射角が $0^{\circ}$ から $90^{\circ}$ 一変化すると, 吊荷動摇量 は水平変位が増加し, 鉛直変位は $45^{\circ}$ を超えると減 少する. これは船体Pitch が卓越しているとジブ トップは上下に動摇し, 船体Roll が卓越していると, ジブトップが左右に動摇するためである.

・船体Pitch と吊荷鉛直の動摇は $45^{\circ}$ で最大になる.

\section{e) 起重機船Bの動摇 (CASE5)}

図-11 は表-3 の実験CASE 5 における，入射波周期と船 体動摇角および吊荷動摇量の関係を示したものである. このケースは，表-1，2 のように起重機船の船体が小さ く，吊荷の水中重量が非常に軽いケースである.

・吊荷の鉛直変位は船体Pitch の影響を受けており連 動している.

- 船体Pitch と吊荷鉛直の傾向は，周期が長くなると 動摇が増加する.

・船体Roll の動摇は周期が長くなると増加する.

- 船体Roll と船体Pitch の動摇は，起重機船B の固有周 期7.4s 付近でピークが見られない. これは船体と吊 荷の連成運動の効果が大きいことが考えられる.

・吊荷水平の動摇は，8s で最大となっており船体Pitch の動摇と一致していない.これは吊荷が2 点吊りで あるため，吊荷自体が回転しやすくその影響を受 けている.

起重機船Aによる一括設置（図-8）と起重機船Bによ る分割設置（図-11）を比較すると以下のことが言える.

・船体動摇はPitch とRoll 共に起重機船B が大きい.

・吊荷水平の動摇は分割設置の方が大きい.

・吊荷鉛直の動摇は同程度である。これは起重機船B のPitch 回転軸から吊荷までの離隔が，起重機船A よ り短いため, 船体Pitch が大きくなっても, 吊荷の 変位が小さくなるためである.

\section{4. 数值シミュレーション}

\section{(1) 数值計算法}

潮流発電装置の据付作業では，波浪により起重機船 が動摇して据付精度が低くなる場合がある。このため, 施工限界波高を精度よく推定することが重要である. 様々な条件で施工条件を検討するために，河邊ら ${ }^{3)}$ が開 発した起重機船と水中吊荷の連成運動の数值計算法を用 いて計算した．起重機船に働く流体力を，3 次元特異点

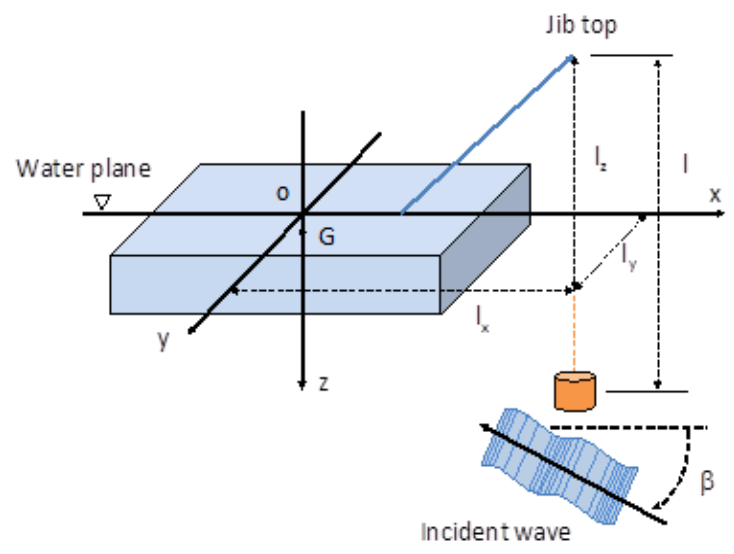

図-12 座標系 
法を用いて求め, 水中吊荷の連動を考慮して両者の連成 運動方程式を周波数領域において解くものである. 計算 における仮定は以下のとおりである。

- $x$ 軸と角度 $\beta$ とな寸, 振幅 $h$, 円周波数 $\omega$ の規則波が 起重機船に入射寸る.

・起重機船，吊荷の運動は微小振幅運動とする.

- 起重機船, 水中の吊荷との流体力学的干渉は無視 できるものとする.

・吊荷は，起重機船からタガーあるいは索によって回 転運動の防止策が取られているとし，xyz 軸方向の 併進運動のみを行うものとする.

座標系は図-12 に示寸ように，起重機船に固定した $x y z$ 座標を取り, ジブトップの座標を $\left(l_{x}, l_{y}, l_{z}\right)$ として, ジブトップから長さlの位置に吊荷が吊り下げられてい るものとする. 起重機船と吊荷の9 自由度の運動方程 式は次式となる.

$$
\begin{array}{r}
\sum_{j=1}^{9}\left[\left(m_{i j}+A_{i j}\right) \ddot{X}_{j}+B_{i j} \dot{X}_{j}+C_{i j} X_{j}=E_{i}\right. \\
\text { for } i=1 \sim 9
\end{array}
$$

ここに， $i, j$ はそれぞれ起重機船および吊荷の各運 動モードを示し， $m_{i j}$ は質量, $A_{i j}$ は付加質量, $B_{i j}$ は造 波減衰力係数, $C_{i j}$ は復元力係数, $E_{i}$ は入射波強制力 を示す，起重機船の動摇に対する減衰については，矩 形の形状を考慮して Roll および Pitch について非線形 減衰係数を考慮する，吊荷については，流体の粘性影 響, 渦の発生を考慮して Morison 式の減衰項を加えて 起重機船と吊荷の連成運動の運動方程式を定式化して いる. また，起重機船および吊荷それぞれの非線形減 衰影響は，それぞれを個別に考慮することができる.

一般に，起重機船と吊荷の応答関数は，ある周波 数範囲に集中した形状になり, 波スペクトルも平均波 周期付近の狭い範囲にエネルギーが分布する の. した がって, 不規則波中の起重機船, 吊荷の応答スペクト ルは狭帯域のスペクトルとなる. このような, 不規則 時系列のピーク值の確率分布は Rayleigh 分布によって 表現できるため，起重機船および吊荷の不規則波中で の応答は，これを統計処理することによって評価する ことができる.

\section{(2) 数值解析の再現性 (CASE6)}

図-13 15 は，有義波波高 $\mathrm{H}_{13}=1.0 \mathrm{~m}$ の不規則波に対 寸る, 起重機船A と水中吊荷の動摇の数值計算結果と実 験結果を示したものである. 図中の縦軸は，それぞれ船 体動摇角度, 水中吊荷の動摇量, 吊荷の動摇速度を, 入

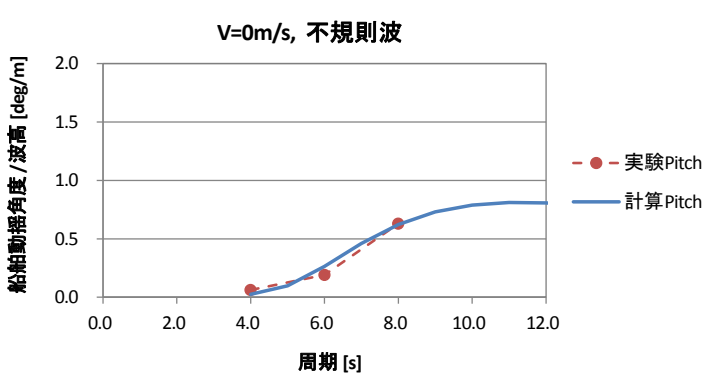

図-13 船舶の動摇角（船体）

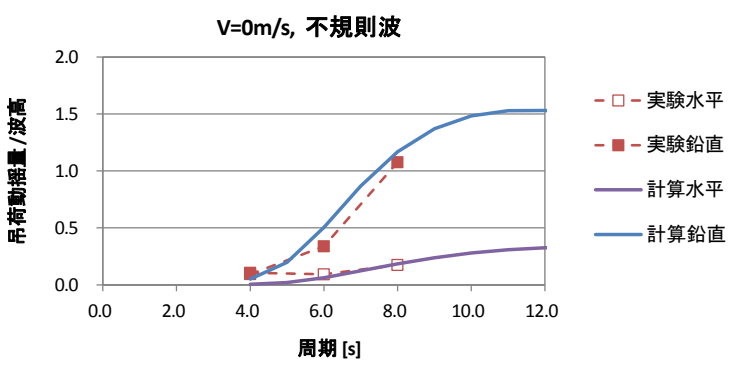

図-14吊荷の動摇量（水中吊荷）

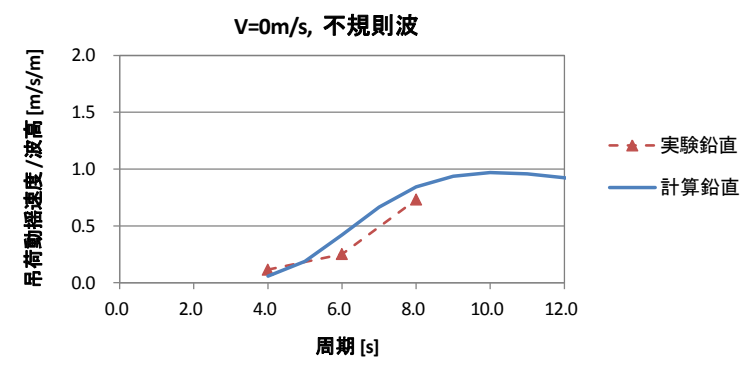

図-15 吊荷の動摇速度（水中吊荷）

射波波高との比で示している. 船体動摇角度と水中吊荷 の動摇量の計算値は，実験結果と良く一致している．ま た，水中吊荷の動摇速度についても計算結果の再現性は 高い.

\section{(3) 施工限界の波浪条件の推定}

発電装置一括設置の施工管理基淮は，水平変位と装置 の傾斜，着底速度である．着底速度は岩盤への着底時の 衝撃による発電装置の破損を考慮して規定しており, 着 底時の鉛直速度を $0.8 \mathrm{~m} / \mathrm{s}$ 以下にする必要がある. 水平変 位は $\pm 10 \mathrm{~m}$ 以下であるが，図-14 のように吊荷の水平変 位は, 有義波周期 $4 \sim 8$ 秒で波高の半分以下であり, 鉛 直速度よりも作業ができる限界波高は大きい.

図-16 は，図-15 で示した水中吊荷の動摇速度の最大 值の安全率を 2 倍と設定して, 据付管理基淮から施工限 界波高を逆算したものである，ただし，動摇速度の最大 值の安全率を何倍にするかは，安全性や施工精度を考慮 して今後検討する必要がある. 図中の緑線で示した範囲 は，起重機船関係者のヒアリングによる経験的な施工限 界で有義波高 $0.5 \mathrm{~m}$ ，周期 $6.0 \mathrm{~s}$ である。これは実験と計 


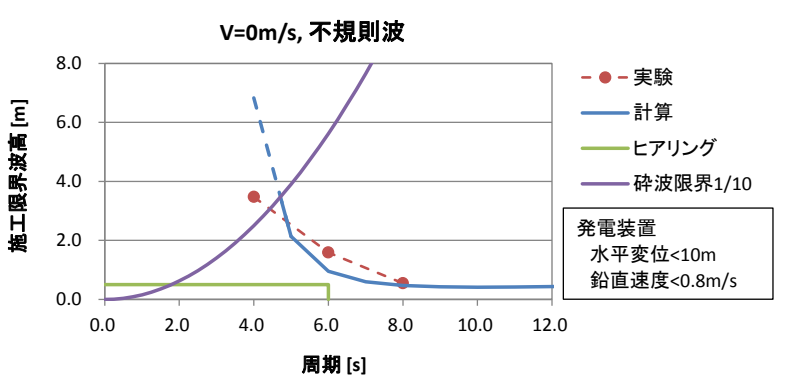

図-16 入射波周期と施工限界波高

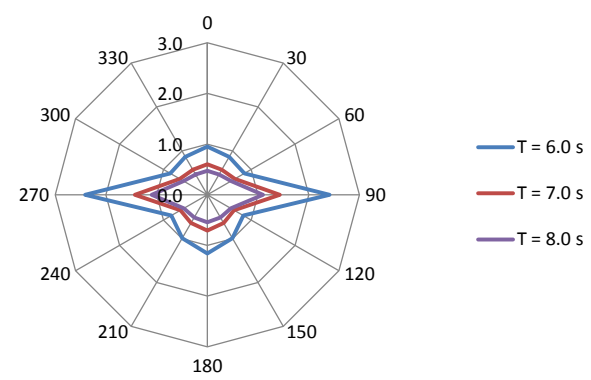

図-17 波浪入射角と施工限界波高

算で求めた施工限界波高に対して十分な余裕があり，動 摇の影響を受けずに作業が可能である.

図-17 は起重機船に作用する波の入射角と吊荷の鉛直 速度に対する施工限界波高の関係を示したレーダーチャ 一トである．放射軸が波の入射角で，中心から外一向か う軸が施工限界波高である。例えば，周期6 秒での波が 入射角 $0^{\circ}$ で起重機船に作用する時は，波高 $1.0 \mathrm{~m}$ まで据 付作業が可能である. この様なレーダーチャートを作成 することで, 動摇量の観点から施工限界を容易に推定す ることが可能であり，作業の安全性の向上や施工精度の 推定に供することができる.

\section{5. おわりに}

本研究は起重機船で潮流発電装置を水中に吊下げた時 の動摇特性について，模型実験と数值計算を実施し，次 のことを明らかにした。
起重機船 $\mathrm{A}$ の実験では，船体と吊荷が最大動摇とな る周期は，Pitchの固有周期とほぼ一致する，吊荷鉿直 は船体 Pitchの影響を強く受ける，船体 Pitch と吊荷鉛直 の動摇は流速の影響が小さい。 また，起重機船 B の実 験では，起重機船 Aよりも船体動摇が Pitch と Roll で大 きくなり，吊荷は水平変位が大きくなるが，鉛直変位は Pitch回転軸から吊荷までの離隔が短いため, 同程度に なる. 数值計算では, 船体動摇と水中吊荷動摇を精度良 く再現できる．また，吊荷の動摇から作業可否判断をす る方法を提案した．経験的な施工限界は十分な余裕のあ る波浪条件であることが明らかになった。

謝辞 : 本研究は，環境省の業務委託として川崎重工・東 亜・古河電工・九州大コンソーシアムで実施した. 本研 究を進めるにあたっては，環境省地球環境局の諸氏に多 大なるご指導，ご助言を頂いた．ここに謝意を表します．

\section{参考文献}

1) 首相官邸政策会議 : 海洋再生可能エネルギー利用促 進に関する取組について (オンライン), http://www.kantei.go.jp/jp/singi/kaiyou/energy/renewablee nergy.html, 参照 2016-05-24.

2) 白石悟，石見剛：アンケートおよび動摇シミュレー ションによる作業船の海上作業限界条件に関する検 討,港湾技研資料， N.898，1998.

3)上田茂, 樋口豊志：起重機船の動摇特性と稼働条件, 港湾技研資料， N.709，1991.

4）宮崎哲史，武田将英，倉原義之介，浅沼丈夫，津田 宗男, 河邊寛: 波浪中の起重機船と吊フック，シャ ックルの連成運動, 土木学会論文集 B2(海岸工学), Vol. 70, No. 2, pp.1051-1055, 2014.

5) 河邊寬，津田宗男，宮崎哲史，倉原義之介，松田信 彦，諫山太郎：吊り荷が水中にある時の起重機船の 波浪中の運動, 日本船舶海洋工学会講演会論文集, 21 号, p.495-498, 2015.

6) 山内保文：船舶・海洋技術者のための不規則現象論, 海文堂出版, 1986.

(2016.5.26 受付)

\section{THE UNDERWATER MOTION OF TIDAL CURRENT POWER GENERATOR DURING CRANE VESSEL LIFTING OPERATIONS}

\section{Nobuhiko MATSUDA, Yoshinosuke KURAHARA, Mikiko EGUCHI, Muneo TSUDA, Aiko KURIHARA, Hiroshi KAWABE}

Japan's energy policy has been changed after the Great East Japan Earthquake. Marine renewable energy is increasing. An advantage of tidal current energies is hardly influenced by weather conditions. Energy can be generated both day and night. During the installation work of tidal power generation device, the vessel and the suspended load are moving by the waves and tidal currents. As a result, the installation accuracy of the suspended load is reduced. Therefore, it is important to understand the motion characteristics of the vessel and the suspended load. This study examined the characteristics of movement during installation of tidal power generation device using a crane vessel in the hydraulic model experiment. 